UNIVERSITA' DEGLI STUDI DI BERGAMO

DIPARTIMENTO DI INGEGNERIA GESTIONALE

QUADERNI DEL DIPARTIMENTO ${ }^{\dagger}$

Department of Economics and Technology Management

Working Paper

n. $04-2012$

Short covering and price stabilization of IPOs

by

Andrea Signori, Michele Meoli, Silvio Vismara

${ }^{\dagger}$ Il Dipartimento ottempera agli obblighi previsti dall’art. 1 del D.L.L. 31.8.1945, n. 660 e successive modificazioni. 


\section{NOTE}

I Working Papers della Collana dei Quaderni del Dipartimento di Ingegneria Gestionale costituiscono un servizio atto a fornire la tempestiva divulgazione dei risultati dell'attività di ricerca, siano essi in forma provvisoria o definitiva.

I Working Papers della Collana sono pubblicati nell'archivio istituzionale dell'Università degli studi di Bergamo (Aisberg): http://dspace-unibg.cilea.it/handle/10446/370. 


\title{
Short covering and price stabilization of IPOs
}

\author{
Andrea Signori ${ }^{a}$, Michele Meoli ${ }^{a, b, *}$, Silvio Vismara ${ }^{a, b}$ \\ a Department of Economics and Technology Management, University of Bergamo, Italy \\ b CCSE, University of Bergamo, Italy, and University of Augsburg, Germany
}

\begin{abstract}
The price stabilization service consists of purchasing shares in the aftermarket in order to prevent price drops, and it is not mandatory. Using a sample of Italian IPOs, we find that only half of the IPOs that require this service are actually stabilized after going public and that price support is substantial for poorly performing IPOs. Nevertheless, the fees charged are not informative about the provision of this ancillary activity. Rather, the underwriter's reputation is negatively associated to the stabilization activity. Negative price revisions and negative (or low) underpricing, also drive the provision of these services.
\end{abstract}

Keywords: IPOs; Underwriters; Investment banks; Gross spread; Price stabilization.

JEL Code: G15, G24

*Contact author: via Pasubio 7b, 24044 Dalmine (BG), Italy, tel.: +39 035 2052023, fax: +39 035 2052077, michele.meoli@unibg.it. 


\section{Introduction}

Underwriters underprice IPOs and often, immediately after, repurchase shares in an attempt to stabilize the price. The theoretical explanations proposed by the literature for this phenomenon are very diverse. For instance, the option to stabilize can be interpreted as a put option offered to informed (institutional) investors as a reward for revealing information before the IPO (Benveniste, et al., 1996), or as a put option to recompense uninformed investors for the "winner's curse," in the spirit of Rock (1986) model (Chowdhry and Nanda, 1996). Despite several attempts (e.g. Wilhelm, 1999; Chen and Wilhelm, 2008; Zhang, 2004), the underwriters' conduct after the issue, when price stabilization is provided, remains opaque (Aggarwal, 2000).

The empirical studies on the price stabilization activity, however, are relatively few (Ruud, 1993; Hanley, et al., 1993; Schultz and Zaman, 1994; Benveniste, et al., 1998) perhaps because of the difficulties in accessing data. One obstacle with testing is that underwriters do not formally commit to price support, nor do they publicly disclose stabilizing activities. Underwriters do not explicitly commit to price support but, instead, decide ex post whether, and how much, to stabilize. Perhaps, a legally binding contract could be too costly to define (under what conditions the underwriter provides price support? how many shares and at what prices?) and to enforce (Lewellen, 2006). However, since trading activity may be profitable for underwriters, they may be motivated to intervene also when not needed. Viceversa, they may be reluctant to stabilize the price of IPOs when it is costly. Ellis et al. (2000) demonstrate that underwriters take substantial inventory positions when stabilizing stock price. The provision of price stabilization may therefore be subject to opportunistic behaviors from the underwriters, as it is an intrinsically profitable activity. 
In this paper, we question whether the price stabilization activity is carried out by underwriters when actually needed. To this end, we employ Heckman and Tobit models to investigate the determinants of the underwriter's decision to grant price stabilization. The empirical setting of our paper is Italy, where we can access unique data provided by the stock exchange (Borsa Italiana), that enable us to identify the IPOs that were stabilized. We find that only half of the IPOs that require this service are actually stabilized after going public, that price support is substantial for poorly performing IPOs, and that underwriter's reputation is negatively associated with the stabilization activity.

The remainder of the paper is organized as follows. Section 2 explains the research design and methodologies. Results are summarized in Section 3, and Section 4 concludes the article.

\section{Research design}

\subsection{Institutional setting}

This paper focuses on the IPO market in Italy, for which we have data on the entire population of IPOs in the period $1999-2008^{\dagger}$. Investigating the Italian underwriting market may be instructive, as its institutional setting is similar to most continental European countries, but significantly different from the US market (Abrahamson, et al., 2011). In Europe, the price stabilization activity is never mandatory, can be done in the first month of trading and cannot be done above the offering price, as regulated by the Commission Regulation 2273/2003. Allocation devices such as overallotment, a naked short position, and the greenshoe option are critical in both the decision and the extent of

\footnotetext{
${ }^{\dagger}$ We are grateful to Fabio Braga, Enrico Pellizzoni and Borsa Italiana for providing proprietary data and useful insights.

Data on underwriter services in the aftermarket are available only until 2008, due to a change in disclosure policies.
} 
stabilization ${ }^{\ddagger}$. Aggarwal (2003) shows that underwriters are used to short-sell IPO shares to the participants ('overallotment'). The short position is then covered either by exercising the 'green shoe' option (in the case of positive initial returns) or by open market repurchases (in the case of weak initial returns, thus supporting the demand for shares and stabilizing the price).

\subsection{Sample and data}

The sample consists of 167 IPOs taking place in Italy in the period from 1999 to 2008, in which the underwriter declares to stabilize the market price, if needed. We collect information on the characteristics of firms, offers, and underwriting syndicates directly from IPO prospectuses. Information regarding price stabilization and liquidity support is provided by Borsa Italiana through the MarketConnect database. In particular, we access the amounts of shares bought and sold by underwriters for stabilization and liquidity support purposes throughout the first month of trading. This information allows us to identify which IPOs are price-stabilized by underwriters, and to what extent ${ }^{\S}$.

\subsection{Methodology and variables}

In this paper, we investigate the determinants of the underwriter's decision to stabilize the price and the factors influencing its intensity. Since the intensity of the price stabilization activity is observable only when the underwriter decides to intervene, we correct for

\footnotetext{
\# Overallotment occurs when the underwriter sells more shares than the issuer made available, by borrowing them from pre-IPO shareholders. The balance can be covered by giving back the corresponding amount of money (greenshoe) and/or shares (stabilization) to the lenders. In the first case, the underwriter can exercise the greenshoe option up to 30 days after the listing, and pay for shares at the offer price independently from the current market valuation. In the second case, the underwriter buys shares from the aftermarket and gives them back to the lenders. A naked short position occurs when overallotment is greater than $15 \%$ of the offer volume. The presence of a naked short position implies stabilization, since the greenshoe option is limited to $15 \%$ of offer volume. The greenshoe option and stabilization are not mutually exclusive. The choice of which strategy to adopt is determined by the aftermarket stock price: if it rises, buying shares would be more costly than exercising the greenshoe. Hence, stabilization is typically associated with poorly performing IPOs and is aimed at preventing price drops.

${ }^{\S}$ Stabilization data are disclosed in a report transmitted to Borsa Italiana by the underwriter at the end of the first trading month.
} 
selection bias by employing a two-step Heckman procedure. In the first step, the dependent variable is a dummy related to the underwriter's decision. Price performance during the first month is the driver for the provision of this service, but it is in turn influenced by stabilization activity, hence endogenous. Therefore, we adopt an instrumental variable approach by employing the following instruments ${ }^{* *}$ for the 1-month buy-and-hold abnormal return: pre-IPO market return, i.e. the return of the FTSE Italia MIB Index over 100 days prior the IPO; market momentum, i.e. the number of IPOs in Italy in the 12 months before listing; underpricing, i.e. the difference between the 1st day closing price and the offer price, in percentage of offer price; and claw back clauses to retail investors, ${ }^{\dagger \dagger}$ i.e. the fraction of shares shifted from institutional to retail investors, as percentage of the offer volume.

We consider variables in three categories: (1) firm and offer characteristics; (2) underwriter characteristics; (3) the options of the underwriters. ${ }^{\ddagger}$

In the first group, we employ firm age at the IPO as a proxy for maturity, while size controls for economies of scale. We also include relative issue size, dilution ratio, and institutional allocation. To control for market conditions, we add the return of the FTSE Italia MIB index 100 days before the listing date (pre-IPO market return), and the number of IPOs in the previous twelve months (market momentum). Finally, we include price revision, claw-back clauses, and underpricing to control for the characteristics of the

\footnotetext{
*** Endogeneity of the 1-month BHAR is verified through Hausman (Hausman, J. A., 1978. Specification Tests in Econometrics. Econometrica 46, 1251-1271.) test. Valid instruments must both explain stock performance and be uncorrelated with the second stage regression residuals. Once tested their validity, we checked exogeneity with respect to the dependent variable in the main equation and excludability from the regression through Hansens's J test.

${ }^{\dagger}$ Claw-back clauses are provisions allowing the underwriter to shift shares from one investor category to another, in order to manage different levels of oversubscription. Bertoni et al. (Bertoni, F., Lugo, S., and Giudici, G., 2008. The Strategic (Re)Allocation of IPO Shares. Politecnico di Milano.) find that underwriters in Italy increase the fraction of the shares allotted to the public when the first day return is negative.

$¥$ A detailed definition of the variables is reported in the Appendix.
} 
offer. Pre-IPO market return, institutional allocation, price revision and underpricing are proxies for performance ${ }^{\S \S}$, while other variables such as firm size and offer characteristics are expected to influence the intensity of the stabilization.

The second set of determinants is related to the underwriter. First, we include a dummy to indicate when non-Italian banks are involved in the process. The underwriter's reputation is proxied by its market share (proceeds) in the Italian market. ${ }^{* * *}$ The size of the underwriting syndicate is also included, because large syndicates allow to share the IPO risk (Torstila, 2001). We include the underwriter' the gross spread (how much underwriters are paid for taking the company public) to see whether fess have any predictive power regarding the price stabilization activity. ${ }^{\dagger \dagger \dagger}$

The third group includes variables measuring the options of the underwriters: the greenshoe, the overallotment, and the naked short option. For each option, dummies are used on the first regression to test the decision to stabilize, while the volume is used in the second regression on stabilization intensity.

\section{Results}

We examine the underwriters' conduct in providing price stabilization and liquidity support. Figure 1 offers a clear picture of how underwriters cover the initial short position, undertaken in $62.6 \%$ of the IPOs. The graph refers to the end of the first month of trading, and shows the average fraction covered by exercising the greenshoe option,

\footnotetext{
$\$ \$$ We checked the validity of these variables by testing relevance (correlation with the endogenous explanatory variable) and exogeneity (no correlation with the error terms).

${ }^{* * *}$ We also defined underwriter reputation with reference to the number of IPOs managed instead of capital raised, finding similar results. These models are not reported in this paper.

${ }^{\dagger \dagger}$ As reported in Table 1, the median gross spread in Italy is 4\%, lower than the tradition 'seven percent solution of US, but in line with previous studies in Europe (Chen, H. C., and Ritter, J. R., 2000. The seven percent solution. Journal of Finance 55, 1105-1131.; Ljungqvist, A. P., Jenkinson, T., and Wilhelm, J., William J., 2003. Global Integration in Primary Equity Markets: The Role of U.S. Banks and U.S. Investors. Review of Financial Studies 16, 63-99.).
} 
and the average fraction covered by stabilizing the IPO, both expressed in percentage of the initial short position (i.e., $100 \%$ corresponds to the sum of overallotment and naked short, if any). IPOs are categorized in four groups, according to the number of days within the first month in which the IPO is traded below the offer price.

\section{[FIGURE 1]}

The largest fraction of short position is covered using the greenshoe option, which is exercised at a nearly constant rate, regardless of price trends. This is not particularly surprising, as underwriters have the incentive to exercise the greenshoe even for offerings that trade below the offer price, because they earn fees in percentage of all the shares issued. Price stabilization is more intense in bad performing offerings, confirming that aftermarket performance drives its provision. However, some stabilization activity occurs even when the stock price keeps persistently higher than the offer price. Stabilizing well performing offerings is costly for underwriters, and raises some questions about their behavior in the provision of aftermarket services.

Therefore, we try to unveil the determinants of the stabilization decision using a Heckman selection model. We include overallotment, naked short, and greenshoe dummies to control for short covering (i.e., 'non discretional' stabilization). The results of this model are shown in Table 1.

\section{[ TABLE 1 ]}

Underwriters do seem to support bad performing IPOs. The coefficient of the instrumented variable for the first month buy-and-hold abnormal return is significantly negative, documenting that a poor aftermarket performance triggers the provision of this 
service. Additionally, IPOs that experience a downward price revision are more likely to be stabilized.

However, foreign and more reputable underwriters are less likely to stabilize the issue. This result is in contrast with the findings of Lewellen (2006) that examines IPOs on the Nasdaq from 1996 yo 1999, finding a strong positive association between price support and underwriter size. Lewellen (2006) argues that underwriter reputation could be positively associated with stabilization activity ("reputation hypothesis") for two reasons. First, while overpricing may hurt the underwriter's reputation, the following price support can be viewed as an ex post action to repair the damage. Second, since stabilization is a discretionary activity, rather than a legally binding commitment, an higher reputation should increase the probability of this commitment to be honored. By contrast, our result is, in practice, an evidence of a "reversed reputation hypothesis" on the Italian market. The negative association between reputation and stabilization activity may be explained by the matching between issuer and underwriter (Fang, 2005): prestigious banks have stricter standards, so take public only high-quality firms which are less likely to underperform and are therefore less likely to need price support.

Conversely, the entity of the gross spread does not predict the decision to stabilize the price. Surprisingly, the overallotment, greenshoe option, and naked short dummies are not significant, even though all three should be crucial in the stabilization decision (short covering). These results point out that underwriters still act with a certain degree of discretion. The second column documents that neither offer size nor the extent of the short position (overallotment and naked short) are influential on the intensity of stabilization. Instead, the negative coefficient of the exercised greenshoe option confirms its substitutability for price stabilization. 


\section{Conclusions}

This paper investigates short covering and price stabilization of IPOs, in a sample of 167 IPOs in Italy from 1999 to 2008 . Only half of the IPOs with the underwriter 'available' to stabilize are then actually 'stabilized'. We investigate which factors determine this decision. In general, underwriters do seem to stabilize IPOs that actually need it, since bad performing offerings experiencing downward price revisions are more likely to be price-supported. Hence, underwriters act according to the issuer's interest. We also test whether the level of fees anticipates the actual provision of this ancillary service, but the results do not show any predictive power.

The nationality and reputation of the underwriter are also crucial in the stabilization decision: foreign and highly ranked banks act less promptly to support stock prices, probably because they take public only high-quality firms that are less likely to underperform. This results provide insights on why only half of the IPOs in Italy actually receive price stabilization. After controlling for all determinants that can discriminate offers expected to be riskier, the underwriter's reputation has a significant impact on the likelihood for an IPO to receive price stabilization. In practice, our results support the idea that underwriters with a better reputation are better in identifying, through unobservable characteristics, those issues that will not need any stabilization activity.

While a rich previous literature documents how underwriter reputation may signal the best IPOs (in terms of underpricing, post-IPO performance, etc.), to the best of our knowledge our paper is the first to provide evidence that underwriters with a better reputation identify offers that will receive less price stabilization. 
Nevertheless, our result is in contrast with the findings of Lewellen (2006), that finds a positive association between underwriter reputation and price support on the Nasdaq, between 1996 and 1999. Why underwriter's reputation has a different relationship with price stabilization on different markets is still a puzzle, and calls for future comparative research. 


\section{References}

Abrahamson, M., Jenkinson, T., and Jones, H., 2011. Why Don't U.S. Issuers Demand European Fees for IPOs? Journal of Finance 66, 2055-2082.

Aggarwal, R., 2000. Stabilization Activities by Underwriters after Initial Public Offerings. Journal of Finance 55, 1075-1103.

Aggarwal, R., 2003. Allocation of initial public offerings and flipping activity. Journal of Financial Economics 68, 111-135.

Benveniste, L. M., Busaba, W. Y., and Wilhelm Jr, W. J., 1996. Price stabilization as a bonding mechanism in new equity issues. Journal of Financial Economics 42, 223-255.

Benveniste, L. M., M. Erdal, S., and Wilhelm Jr, W. J., 1998. Who benefits from secondary market price stabilization of IOPs? Journal of Banking \&amp; Finance 22, 741-767.

Benveniste, L. M., and Spindt, P. A., 1989. How Investment Bankers Determine the Offer Price and Allocation of New Issues. Journal of Financial Economics 24, 343-361.

Bertoni, F., Lugo, S., and Giudici, G., 2008. The Strategic (Re)Allocation of IPO Shares. Politecnico di Milano.

Chen, H. C., and Ritter, J. R., 2000. The seven percent solution. Journal of Finance 55, 11051131.

Chen, Z., and Wilhelm, W. J., 2008. A theory of the transition to secondary market trading of IPOs. Journal of Financial Economics 90, 219-236.

Chowdhry, B., and Nanda, V., 1996. Stabilization, Syndication, and Pricing of IPOs. Journal of Financial and Quantitative Analysis 31, 25-42.

Ellis, K., Michaely, R., and O'Hara, M., 2000. When the Underwriter Is the Market Maker: An Examination of Trading in the IPO Aftermarket. Journal of Finance 55, 1039-1074.

Fang, L. H., 2005. Investment bank reputation and the price and quality of underwriting services. Journal of Finance 60, 2729-2761. 
Hanley, K. W., Kumar, A. A., and Seguin, P. J., 1993. Price Stabilization in the Market for New Issues. Journal of Financial Economics 34, 177-197.

Hausman, J. A., 1978. Specification Tests in Econometrics. Econometrica 46, 1251-1271.

Kim, D., Palia, D., and Saunders, A., 2010. Are Initial Returns and Underwriting Spreads in Equity Issues Complements or Substitutes? Financial Management 39, 1403-1423.

Lee, I., Lochhead, S., Ritter, J., and Zhao, Q., 1996. The costs of raising capital. Journal of Financial Research 19, 59-74.

Lewellen, K., 2006. Risk, Reputation, and IPO Price Support. The Journal of Finance 61, 613653.

Ljungqvist, A. P., Jenkinson, T., and Wilhelm, J., William J., 2003. Global Integration in Primary Equity Markets: The Role of U.S. Banks and U.S. Investors. Review of Financial Studies 16, 6399.

Lowry, M., 2003. Why does IPO volume fluctuate so much? Journal of Financial Economics 67, $3-40$.

Rock, K., 1986. Why new issues are underpriced. Journal of Financial Economics 15, 187-212.

Ruud, J. S., 1993. Underwriter price support and the IPO underpricing puzzle. Journal of Financial Economics 34, 135-151.

Schultz, P. H., and Zaman, M. A., 1994. Aftermarket Support and Underpricing of Initial Public Offerings. Journal of Financial Economics 35, 199-219.

Torstila, S., 2001. What determines IPO gross spreads in Europe? European Financial Management 7, 523-541.

Wilhelm, W. J., 1999. Secondary Market Stabilization of IPOs. Journal of Applied Corporate Finance 12, 78-85.

Yeoman, J. C., 2001. The optimal spread and offering price for underwritten securities. Journal of Financial Economics 62, 169-198.

Zhang, D., 2004. Why Do IPO Underwriters Allocate Extra Shares when They Expect to Buy Them Back? Journal of Financial and Quantitative Analysis 39, 571-594. 


\section{Table 1. Heckman selection model on stabilization activity}

Sample of 167 Italian IPOs from 1999 to 2008 in which the underwriter declared to stabilize stock price if needed. Average, median, coefficients and statistics (in brackets) are reported. The dependent variables are: in step 1, stabilization dummy, equal to 1 if the underwriter stabilizes stock price; in step 2, stabilization intensity, i.e. the number of traded shares to stabilize stock price during the first month, scaled by first month turnover. Control dummies: industries, years, privatizations, ECOs, private placings, markets, VC-backing. Independent variables: firm age is the age in years of the company at the IPO; issue size is the log of IPO proceeds expressed in 2008 Euros; relative issue size is the offer volume in percentage of pre-IPO outstanding shares; dilution ratio is the fraction of newly issued shares as percentage of pre-IPO outstanding shares; institutional allocation is the fraction of shares reserved to institutional investors by prospectus; pre-IPO market return is the return of the FTSE Italia MIB Index over 100 days prior the IPO; price revision is the percentage difference between offer price and midpoint of the preliminary price range; 1-month $B H A R$ is the instrumented variable for aftermarket performance; foreign underwriter is the percentage of IPOs underwritten by a non-Italian bank; underwriter reputation is the fraction of capital raised in the sample, scaled at 1 for the 'national champion' Mediobanca; syndicate size is the number of members of the underwriting syndicate; gross spread is the underwriter's remuneration, in percentage of IPO proceeds; overallotment is a dummy equal to 1 in case of the underwriter sells shares in excess of the offered volume; greenshoe is a dummy equal to 1 in case the greenshoe option is exercised; naked short is a dummy equal to 1 in case the underwriter overallocates more than $15 \%$ of the offering; overallotment volume are overallocated shares in percentage of offer volume; greenshoe volume is the fraction of greenshoe exercised (0-15\% of offer volume); naked short volume is the amount of naked short in percentage of offer volume.

a percentage of firms

\begin{tabular}{|c|c|c|c|c|}
\hline & Average & Median & $\begin{array}{l}\text { Step 1. Stabilization } \\
\text { decision }\end{array}$ & $\begin{array}{l}\text { Step 2. Stabilization } \\
\text { intensity }\end{array}$ \\
\hline Firm age (years) & 32.1 & 19.0 & & $\begin{array}{c}0.03 \\
(1.31)\end{array}$ \\
\hline Issue size (€m) & 303.0 & 95.2 & & $\begin{array}{c}0.06 \\
(1.29)\end{array}$ \\
\hline Relative issue size (\%) & 101.7 & 38.8 & & $\begin{array}{l}-0.08 \\
(-0.50)\end{array}$ \\
\hline Dilution ratio (\%) & 26.5 & 25.5 & & $\begin{array}{c}0.25 \\
(1.52)\end{array}$ \\
\hline Institutional allocation (\%) & 74.9 & 75.0 & $\begin{array}{l}-1.33 \\
(-1.06)\end{array}$ & \\
\hline Price revision (\%) & 28.8 & 35.1 & $\begin{array}{c}-3.35 * * * \\
(-3.64)\end{array}$ & \\
\hline 1-month BHAR (\%) & 7.3 & -1.0 & $\begin{array}{c}-1.91 * * * \\
(-2.79)\end{array}$ & \\
\hline Foreign underwriter ${ }^{a}$ & 23.0 & & $\begin{array}{c}-0.97 * * * \\
(-2.93)\end{array}$ & \\
\hline Underwriter reputation (\%) & 22.3 & 6.0 & $\begin{array}{l}-0.82 * * \\
(-2.00)\end{array}$ & \\
\hline Syndicate size (no.) & 2.1 & 2.0 & $\begin{array}{c}0.20 \\
(1.23)\end{array}$ & \\
\hline Gross spread (\%) & 3.9 & 4.0 & $\begin{array}{l}-0.24 \\
(-1.47)\end{array}$ & \\
\hline Overallotment dummy $^{a}$ & 62.6 & & $\begin{array}{l}-0.08 \\
(-0.14)\end{array}$ & \\
\hline Greenshoe dummy ${ }^{a}$ & 61.4 & & $\begin{array}{l}-0.77 \\
(-1.44)\end{array}$ & \\
\hline Naked short dummy ${ }^{a}$ & 4.7 & & $\begin{array}{c}0.92 \\
(1.50)\end{array}$ & \\
\hline Overallotment volume (\%) & 7.2 & 7.8 & & $\begin{array}{c}-0.50 \\
(-1.50)\end{array}$ \\
\hline Greenshoe volume (\%) & 6.8 & 7.5 & & $\begin{array}{l}-0.81 * * \\
(-2.01)\end{array}$ \\
\hline Naked short volume (\%) & 0.2 & 0.0 & & $\begin{array}{c}1.42 \\
(0.67)\end{array}$ \\
\hline Constant & & & $\begin{array}{c}10.9 * * * \\
(3.36)\end{array}$ & $\begin{array}{c}-0.31 \\
(-0.81)\end{array}$ \\
\hline Observations & & & \multicolumn{2}{|c|}{167} \\
\hline Censored & & & \multicolumn{2}{|c|}{74} \\
\hline Wald Chi-square & & & \multicolumn{2}{|c|}{47.3} \\
\hline
\end{tabular}




\section{Figure 1. Short covering activity by underwriters}

The graph shows how underwriters have covered their initial short position at the end of the first month of trading. Dark grey is the fraction covered by greenshoe option, light grey is the fraction covered by price stabilization. Y-axis reports the percentage of short position undertaken by underwriters at the IPO, where $100 \%$ is the sum of overallotment and naked short, if present. Groups on the x-axis refer to the number of days (throughout the first 30 days of trading) in which the official daily price of the stock was below the offer price.

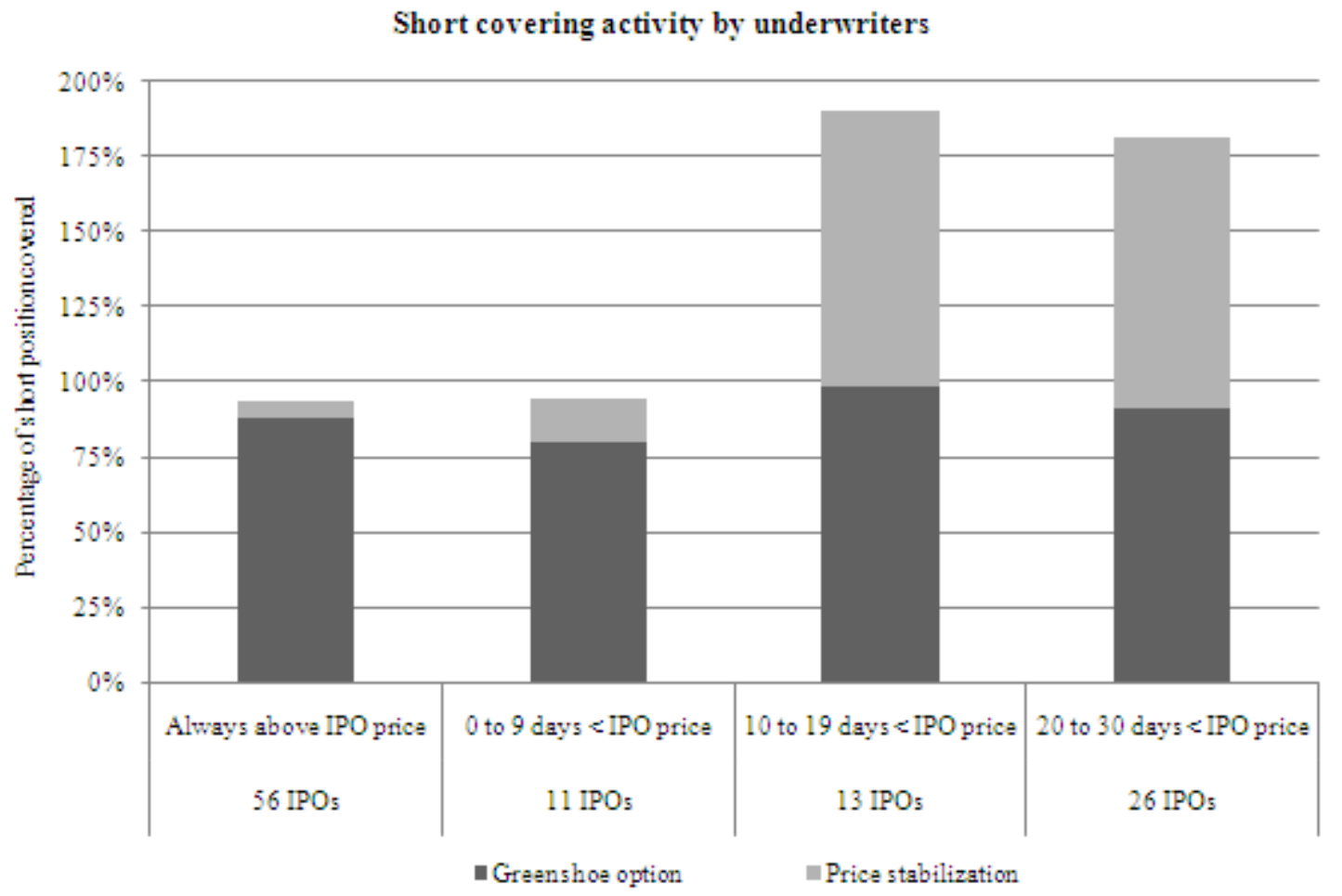




\section{Appendix 1. Variable definitions}

Name Definition

FIRM AND OFFER

Firm age

Issue size

Relative issue size

Dilution ratio

Institutional allocation

Pre-IPO market return

Market momentum

Price revision

Claw-back to retail

\section{Underpricing}

UNDERWRITER

Foreign underwriter

Underwriter reputation

Syndicate size

\section{UNDERWRITER OPTIONS}

Greenshoe dummy (volume)

Overallotment dummy (volume)

Naked short dummy (volume)
Log of 1 plus firm age (in years) at the IPO

Log of IPO proceeds adjusted for inflation, expressed in 2008 Euros

Number of shares offered over pre-IPO outstanding shares

Number of newly issued shares over pre-IPO outstanding shares

Fraction of shares reserved to institutional investors by prospectus

FTSE Italia MIB index return over 100 days prior the IPO

Number of IPOs in the Italian market during the 12 months before listing

Percentage difference between the offer price and the midpoint of the preliminary price range

Fraction of shares shifted from institutional to retail investors after the initia allocation, as percentage of total number of offered shares

Percentage difference between first day official price and offer price

Dummy for non-Italian lead underwriters

Amount of capital raised by the underwriter over the total capital raised in the sample (scaled to 1 = 'national champion' Mediobanca)

Number of members of the underwriting syndicate

Dummy equal to 1 in case the underwriter allocates more shares than made available by the issuer (Fraction of greenshoe of offer volume actually exercised)

Dummy equal to 1 in case the underwriter allocates more shares than made available by the issuer (Amount of shares over-allocated, as percentage of offer volume)

Dummy equal to 1 in case the underwriter overallocates more than $15 \%$ of the offer volume (Fraction of over-allocated shares exceeding the 15\% threshold)
Theoretical background

Higher uncertainty in younger companies

Economies of scale on gross spread (Lee, et al., 1996)

Newly issued shares increase underwriter's valuation uncertainty (Yeoman, 2001)

Institutional participation is necessary for an IPO to be successful (Aggarwal,

2000)

Market returns capture investment opportunities, investor sentiment and other unknown dynamics (Lowry, 2003)

Favorable market sentiment makes trading activity more profitable for underwriters (Ellis, et al., 2000)

Price revision should impound public and private information on investor demand gathered in the bookbuilding process (Benveniste and Spindt, 1989)

Balance of cold demand of informed institutional investors with hot demand of non-informed retail investors (Bertoni, et al., 2008)

Spread and underpricing can be complementary (Kim, et al., 2010)

US banks underwriting European IPOs are more costly (Torstila, 2001)

Reputable banks charge higher fees and provide higher quality services (Fang, 2005)

Syndicate size is important for the IPO risk sharing (Torstila, 2001)

Control for short covering in the decision (intensity) to provide aftermarket support

Control for short covering in the decision (intensity) to provide aftermarket support

Control for short covering in the decision (intensity) to provide aftermarket support 